\title{
Brain drain from vocational to academic education at upper-secondary level? An empirical analysis for Switzerland
}

\author{
Katharina Jaik ${ }^{*}$ (1)
}

\author{
${ }^{*}$ Correspondence: \\ katharina.jaik@uzh.ch; \\ k.jaik@gmx.de \\ Department of Business \\ Administration, University \\ of Zurich, Zurich, Switzerland
}

\begin{abstract}
Despite the ongoing debate about how much academic versus vocational uppersecondary education is favorable for a country and large differences across countries of those two types of education exist, the interplay of vocational and academic education on upper-secondary level and its consequences for the entire education system remain under-researched. Although difficult to analyze directly, we first construct a measure to capture companies' reactions to changes in academic education rates and second analyze whether academic education rates are associated with success rates in vocational education over time and with control variables. To measure companies' reactions, we use a cantonal average requirements profile consisting of the academic requirements profile of an occupation and the number of apprenticeships started in this occupation per year and canton. Although results of the first part of the analysis are ambiguous, combined with the second part, they suggest a non-reaction of companies (i.e., they keep offering the same occupations but have to fill their positions with lower-ability candidates). Results of the second part show that more opportunities for academic education appear to draw highly-able students away from vocational education, with negative consequences for the success rates in vocational education. Our findings have important implications for countries with vocational and academic tracks in their education systems, but also for those who plan to introduce or strengthen (dual) vocational education.
\end{abstract}

Keywords: Vocational education, Academic education, Interplay, Upper-secondary education, Brain drain, Academic requirements profile in VET, Switzerland

\section{Introduction}

The percentages of students choosing either academic or vocational upper-secondary education vary tremendously across countries (Bolli et al. 2017). While the U.S. has only academic education programs in its upper-secondary education systems, Austria has the highest percentage of vocational education and training (VET) programs, with almost $80 \%$ of a cohort choosing this upper-secondary option. In Switzerland, the percentage of VET programs is roughly 65\%, placing it very high relative to the other OECD countries (Bolli 2018, calculations based on OECD data from 2015). 
Clearly, the optimal percentages of academic and vocational programs with respect to labor market outcomes vary from country to country and depend on a number of different country-specific factors. Nonetheless, a complex and controversial discussion about the effects of academic versus vocational education on an individual's transition into the labor market and eventual labor market outcomes remains heated, as both types of education have their advantages and disadvantages. On the one hand, particularly dual VET programs, which combine work-based learning in a company and theoretical learning at a vocational school, are receiving increasing attention for their success in smoothing the transition to the labor market (Bolli et al. 2017; Hampf and Woessmann 2017; Hanushek et al. 2017; SKBF-CSRE 2018). On the other hand, particularly for Switzerland, how similarly able graduates from academic and vocational programs differ in terms of their long-run employment possibilities remains less clear.

Discussions about the advantages and disadvantages of academic and vocational education mostly neglect the interplay between both types of education at the institutional level and its effect on collective outcomes such as graduation rates. However, ensuring constant quality and the ensuing prestige of both academic and vocational education crucially calls for an understanding of that interplay. In Switzerland, one finds a strong negative correlation between the academic education rate and the success rate in final exams in VET (SKBF-CSRE 2014, 2018). Although the VET final exams are national, every academic upper-secondary school can administer its own final exam and also decide on the previous step, i.e. entry criteria for academic upper-secondary education. As entrance into and graduation from academic upper-secondary education varies greatly across the 26 different cantons, ${ }^{1}$ the question arises, whether academic education draws highly-able students away from vocational education in cantons where academic education rates are high.

Under the assumption that ability is equally distributed over the cantons, we expect that in cantons with higher rates of academic education, compared to those with lower rates, highly-able students are shifted away from vocational education to the academic track. Although directly testing this hypothesis at the aggregated level is impossible, a question to answer is whether companies-as the main provider of vocational education in Switzerland-react to differences in academic education rates in different cantons, and if they react, how. They could react by either filling the same occupations with less able students or by ceasing to offer positions in highly demanding occupations. To answer this question, we construct a measure that depicts the average cantonal requirements profile (comprising requirements in language, foreign languages, mathematics, and science) for the mix of apprenticeships started each year. This measure combines data on the numbers of the apprenticeships started in each occupation in each canton with the requirements profile of each occupation, a profile measuring how demanding an occupation is.

Confronted with a high percentage of graduates of academic education, companies could potentially react in two ways. First, they could stop offering apprenticeship

\footnotetext{
${ }^{1}$ A canton is a member state of the Swiss Confederation with responsibilities and power similar to a U.S. state, a Canadian province, and a German Bundesland (federal sate). Switzerland comprises 26 cantons, with a total of four official languages. About 63\% of the Swiss population are German-speaking, 23\% French-speaking, 9\% Italian-speaking, and $0.5 \%$ Raeto-Romanic-speaking.
} 
positions in highly demanding occupations, simply for a lack of appropriate candidates. This option, leading to a reduction in the average cantonal requirements profile, should have no effect on the success rate in vocational education. Second, companies could keep offering apprenticeships in the same occupations as before but (have to) fill them with lower-ability candidates. This option, while leading to a stable average cantonal requirements profile, would result in a decrease in the success rate of vocational education.

In a first step, we test whether the academic education rate is associated with the cantonal requirements profile, that is, whether companies react to changes in the academic education rate. Companies could either react by ceasing to offer highly demanding apprenticeships or by continuing to offer them but filling the positions with a new cohort of potential apprentices who are less able. After indeed finding that the average requirements profile does not appear to react to changes in the academic education rate, we test in a second step whether the observed negative correlation between the academic education rate and the success rate in vocational education also holds over time-compared to the cross-sectional analyses in SKBF-CSRE $(2014,2018)$ - and with the introduction of control variables.

The results provide several important insights. First, we find that the academic education rate is not associated with the cantonal requirements profile in VET. This finding suggests that companies do not react to differences in the cantonal academic education rates by reducing apprenticeship positions in highly demanding occupations. Second, after controlling for the percentage of immigrants and of school-based VET, where all the instruction is provided at full-time, state-funded vocational schools (as opposed to dual VET, where time is shared between company and vocational school), we find that the academic education rate is significantly and negatively correlated with the overall success rate in VET and the success rate in dual VET. Both results, taken together, suggest that companies do not cease to offer highly demanding apprenticeship positions. In other words, they continue offering the same type of apprenticeship positions, simply filling them with lower-ability students, who, in turn, are more likely to fail the final exams. However, given that we also find a highly significant and positive effect for the percentage of school-based VET on the average requirements profile, an alternative explanation is a cantonal overcompensation for the companies' reaction to changes in academic education rates. This positive association indicates, that in fear that companies will react by ceasing to offer highly demanding apprenticeships, the cantons themselves (which offer school-based VET) overcompensate for that potential reaction by offering more school-based VET occupations that are more demanding than the average cantonal requirements profile.

There are two strands of the literature that are partly related to our research questions. The first strand of this literature deals with the interplay between academic and vocational education, the interplay that we focus on in this paper. First, Muehlemann et al. (2018) use a German high school reform, which led to a supply shock of academic graduates in some graduation cohorts and regions, to study the effect of this shock in the market for high-educated apprentices (those with a university entrance qualification $=$ Abitur). They find that companies reacted to the shock by absorbing the additional high school graduates and that there was no substitution effect between apprenticeships requiring university entrance qualification and those that did not. In another study, 
Bolli et al. (2017) use a sample of OECD and associated countries to study the effects of academic education and different types of VET (dual and school-based) on different labor market outcomes. They find that dual VET positively influences the transition to the labor market and job quality, while school-based VET and academic education make the transition more difficult. Our paper complements those two papers by analyzing the preceding step, the interplay that takes place between academic and vocational education before the transition to the labor market.

The second strand of the literature that is relevant for this paper analyzes the impact of central exams on various outcomes. On one hand, this literature consistently shows that central exams improve student outcomes (achievement), have a higher value on the labor market than grades from local exams (higher earnings, lower unemployment) and even increase economic growth (for extensive overviews on the topic of central exams and their effects see, e.g. Hanushek and Woessmann (2011), Schwerdt and Woessmann (2017), and Woessmann (2018)). While those studies mainly focus on central exams in academic education, we study the opposite situation in Switzerland, where no central exams exist in upper-secondary academic education and graduation rates vary greatly, and connect it with success rates in vocational education, where exams are centralized at the national level.

On the other hand, there are two studies by Backes-Gellner and Weckmüller (1998) and Backes-Gellner and Veen (2008) that are from a conceptional point of view closely related to the questions we pose in this paper. Those two studies analyze theoretically and empirically the interplay between different tracks of lower- and upper-secondary education level in Germany and find that the highest demanding tracks on lower and upper-secondary level (Gymnasium and Realschule) draw away students from the least demanding track (Hauptschule) and thereby decrease the quality standards in the highest demanding tracks in regions where final exams are not centralized. While those two studies analyze the important interplay of different levels of education (lower- and upper-secondary education levels), we follow their example in analyzing the same mechanism of drawing away students from one type of education to another, but focus on an interplay at the same level of education, i.e. upper-secondary education. In this paper, we indirectly make use of central exams in vocational education and use the variation in academic education rates across Swiss cantons where no central exams exist.

Although we focus on the upper-secondary level only, it is first, very important to keep in mind that preceding levels of education might influence this interplay, as BackesGellner and Weckmüller (1998) and Backes-Gellner and Veen (2008) show. Second, the interplay between different types of education on the same level (i.e. academic and vocational education at upper-secondary education) might also have consequences for the subsequent level (i.e. tertiary education, see Wolter et al. (2014)).

Although, in the absence of exogeneous shocks or variation, we are not able to identify causal effects, our analyses help to better explain the relationships between both types of upper-secondary education (i.e. academic and vocational education, with their respective subtypes) and point the way ahead for future research. Understanding the interplay between the two types of education is important if countries want to increase their upper-secondary level graduation rates and keep the quality of all types of uppersecondary education constant. Increasing graduation rates at the upper-secondary level 
is critical, because a completed degree at that level is the prerequisite for entering tertiary education and being successful in the labor market (SKBF-CSRE 2018). The OECD goes one step further, pointing out that technological change and digitalization will soon render an upper-secondary degree insufficient for labor market success (OECD 2018).

This paper is structured as follows. In the "Institutional background and simple model" section, we provide information on the institutional background and develop a simple model to explain our predictions. In the "Methods and data" section, we explain the dataset that we compiled. In the "Results" section we present the results. The "Conclusions and discussion" section concludes.

\section{Institutional background and simple model Institutional background}

Figure 1 shows the different types and subtypes of upper-secondary education that currently exist in Switzerland.

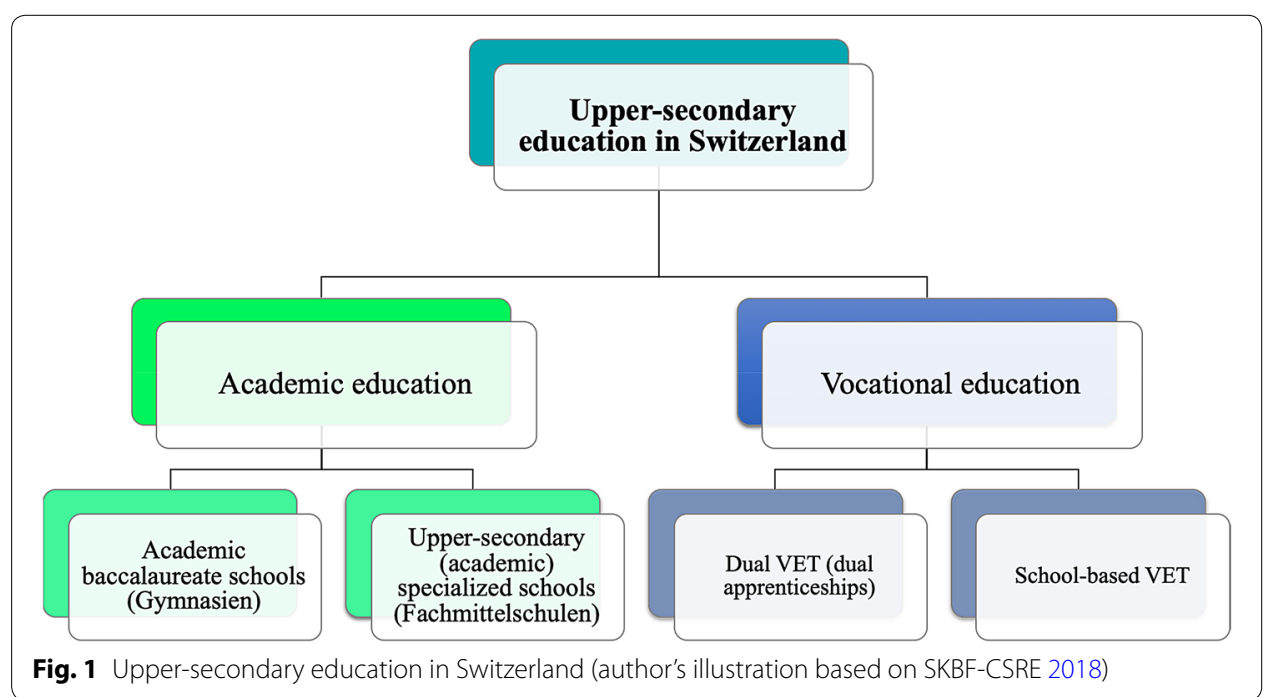

At the upper-secondary level, students in Switzerland must choose between academic and vocational education. While academic education is exclusively for the highest performing students, vocational education offers opportunities for those of almost every level of ability. Most students (around 70\%) choose vocational education, the other 30\% opting for an academic education. The most common form of academic education is the academic baccalaureate school, which leads to qualification for university entrance. In addition, upper-secondary (academic) specialized schools (Fachmittelschulen) offer direct access to Universities of Applied Sciences and Universities of Teacher Education. The final exams for upper-secondary academic education are not standardized across schools-indeed, not even within cantons-and both participation and success rates vary greatly among cantons. For example, in the canton of Basel-Stadt an average of $33.97 \%$ of all upper-secondary students graduate from academic education, whereas in the canton of Glarus an average of only $13.9 \%$ do so. The entry barriers to cantonal baccalaureate schools also vary greatly. 
The most common form of vocational education (more than 90\%) in Switzerland is the dual apprenticeship, combining work-based training and school-based learning. A minority (less than 10\%) of VET is completely school-based and takes place at fulltime vocational schools. Since the 2002 enactment of the Federal Act on Vocational and Professional Education and Training (VPETA) and the corresponding Ordinance on Vocational and Professional Education and Training (VPETO), the final exams and diplomas earned are the same for both dual and the school-based VET. The final exams, standardized at the national level, consist of a practical and a theoretical part. Students who undertake a dual apprenticeship typically have 1-2 days of schooling per week and work the remaining 3-4 days at a company. While full-time vocational school students conduct their apprenticeship mainly at school, for a successful graduation they have to complete an internship in a company, typically in the last year of their apprenticeship. The dispersion of school-based VET depends on the language region: The French- and the Italian-speaking parts of Switzerland traditionally have more school-based options, whereas the German-speaking part offers more dual apprenticeships.

Even though both dual and full-time schooling apprenticeships lead to the same diploma, the allocation process of apprenticeship positions is completely different. In the dual model, the allocation follows market principles (Wettstein and Amos 2010): Companies $^{2}$ offer apprenticeship positions, and students apply for these positions. The application process typically starts 12 to 18 months before compulsory schooling ends at the end of $9^{\text {th }}$ grade. The students (or the students' parents if the students are underage) sign a contract with the employer for the duration of the apprenticeship. In the school-based model, schools can offer apprenticeships after consultation with cantonal authorities and professional organizations, ensuring that the practical training in particular meets labor market needs (VPETO, Art.15). Schools set their own admission requirements.

\section{Simple model}

In this section, we derive two predictions by developing a very simple model inspired by the Swiss system explained in the "Institutional background" section and partly incorporating the theoretical considerations of Backes-Gellner and Weckmüller (1998). Let us assume two types of upper-secondary education, academic and vocational: Academic education is exclusively for high-ability students, while vocational education covers almost all levels of academic ability. In this simple model, students have a preference for academic education, because it gives direct access to university. Hence, they choose academic education if possible, or, if academic education is not feasible, the most demanding option in vocational education. There are different geographic regions, and, across those regions, a big variation exists in the intensity of the two types of education. By choosing the percentage of academic education provided, the regions indirectly define ability thresholds for entering academic education.

Let us further assume that there are no regional differences in student ability and that the criteria for passing the final exam differ across the regions for academic education but not for vocational education.

2 To qualify as training companies, companies have to fulfill different criteria, which are regulated in the VPETA (2002) and VPETO (2003). 


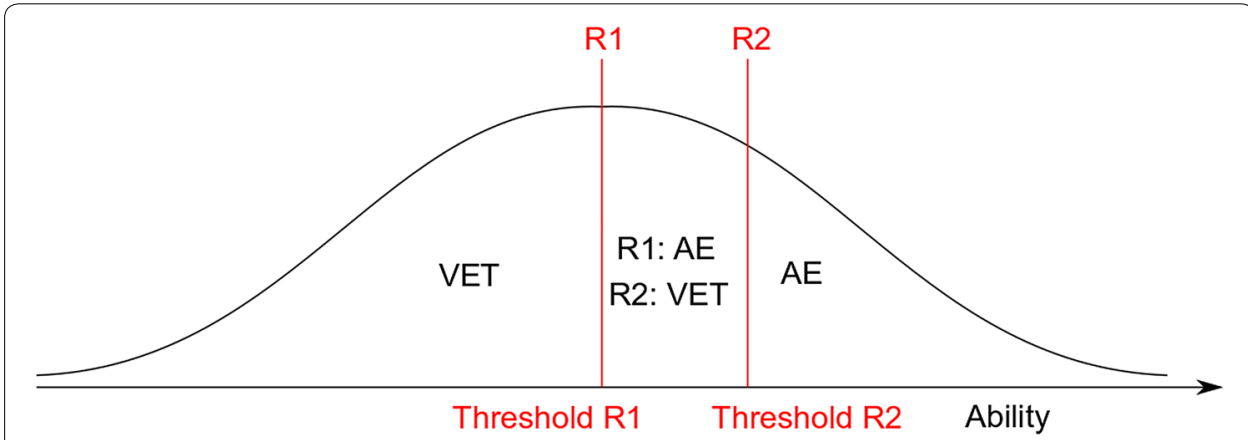

Fig. 2 Distribution of ability within type of education (academic and vocational), dependent on regional rules (author's illustration)

Figure 2 illustrates the relationship between choices and the regional provision of academic education. Ability follows a normal distribution and is the same over different regions. Region 1 (R1) has a larger offer of academic education than region 2 (R2). As a consequence, students with the same ability (between threshold 1 and threshold 2) are in academic education in region 1 but in vocational education in region 2 .

Region 1 companies that want to offer apprenticeship positions to students with high ability (between thresholds R1 and R2) cannot find adequate applicants, because the students they want have chosen academic education. Therefore, companies in region 1 have two possibilities for reacting to this situation:

1. They stop offering highly demanding apprenticeship positions, and the average regional requirements profile in VET decreases. In this case, the ability composition within the remaining apprenticeships is not affected. Thus, the success rate in VET should stay constant. ${ }^{3}$

2. They keep offering highly demanding apprenticeship positions but (have to) fill them with the relatively best candidates available (below threshold R1). This reaction leads to the demanding positions being filled in both regions, resulting in a constant average requirements profile. However, because of a lower average ability of students in VET, but constant requirements of the apprenticeships in region 1, the success rate on the final vocational education exam (which is the same for all regions) will decrease.

Thus far, we have assumed a strict separation between the state (or regions) as provider(s) of academic education and companies as provider of vocational education. We now expand the model such that the state (or regions) may also provide vocational education, mainly in cases where companies cannot or do not want to offer it. The state can offer only school-based VET. The impact of this additional supply from the state on the average requirements profile in the region is not ex ante clear, because it depends on

\footnotetext{
${ }^{3}$ In this scenario, a shortage of skilled workers in the segment of the most demanding apprenticeships in region 1 has to be expected in the long run.
} 
the academic requirements of the positions created. The following two ${ }^{4}$ scenarios can possibly occur if the region decides to offer school-based VET:

1. The average requirements profile in VET in the region stays constant, because the additional positions created have on average similar requirements compared to the current average requirements in VET in the region. ${ }^{5}$

2. The average requirements profile in VET in the region increases, because the additional positions created have on average higher academic requirements than the current average requirements in VET in the region.

From the simple model, we derive the following testable predictions:

Main prediction (P1): A regional increase in the academic education rate leads to either a change in the type of offered apprenticeship positions by companies, i.e. lower average requirements of positions offered or translates into a decrease in the success rate in VET in the region.

Ancillary prediction (P2): If regions start offering school-based VET that is more demanding than the current average requirements in VET and companies do not offer due to a lack of highly-able students, the success rate in VET will decrease. Hence, we expect a negative relationship between the percentage of school-based VET and the regional success rate in VET.

In the "Methods and data" section, we describe the data we use to analyze whether companies react to changes in the academic education rate and to test the relationship between the academic education rate and the success rate in VET.

\section{Methods and data}

For the analysis of the two predictions, we construct a panel dataset, combining data from different publicly available sources. In addition, to proxy the reaction of companies to differences in academic education rates, we construct a measure for the average cantonal requirements profile in vocational education. We use random effects estimations because our data has a panel structure and test statistics suggest that random effects estimations are more efficient than fixed effects.

\section{Sources and two-step data manipulation process}

As most of the data we use in this paper is publicly available from the Swiss Federal Statistical Office (FSO), therefore most of the definitions in this paper are from the FSO unless otherwise referenced. In a first step, we start with the data on individual occupations per year and per canton, combine it with the academic requirements profile per occupation, ${ }^{6}$ and then collapse this data to obtain the average cantonal requirements profile per year. In a second step, we merge the average cantonal requirements profile

\footnotetext{
${ }^{4}$ A third scenario (decrease in the average cantonal requirements profile due to additional positions in occupations with a lower requirements profile than the current average) cannot occur in this model, because students have a preference for the most demanding option in VET and would consequently not choose school-based VET in this scenario, if there are overall enough positions. Therefore, regions would not offer additional school-based VET in this case.

5 An alternative explanation for a constant average cantonal requirements profile would be that regions do not create additional school-based apprenticeship positions.

${ }^{6}$ See https://www.anforderungsprofile.ch.
} 
per year with the cantonal data on academic education rates and success rates in VET (and several control variables) from different sources in the FSO, that we will describe in detail in the sections "Dependent variables" and "Explanatory variables". Descriptive statistics for all variables appear in Table 4 in the Appendix.

\section{Dependent variables}

Average cantonal requirements profile in VET

We define the average cantonal requirements profile in VET as follows:

$$
\overline{A R P}_{c t}=\frac{\sum\left(A R P_{o} * N_{o c t}^{A s}\right)}{N_{c t}^{A s}}
$$

$\overline{A R P}$ denotes the average academic requirements profile in vocational education. This measure $\left(\overline{A R P}_{c t}\right)$ is the sum of the number of all apprenticeships started in a given year and canton (dual and full-time schooling types) ${ }^{7}\left(N_{o c t}^{A s}\right)$ weighted by the academic requirements profile of the respective occupation $\left(A R P_{o}\right)$ and divided by the total number of apprenticeships started per canton and per year $\left(N_{c t}^{A s}\right)$.

The academic requirements of the schooling part of an apprenticeship are based on expert ratings for the respective occupation. They contain the academic requirements in language, foreign languages, mathematics, and science on a scale from 1 to 100 . Measures for the four individual types, as well as an average of the four individual types, are available in the data. ${ }^{8}$ For our main specification, we use the average academic requirements profiles from the four individual types; for a robustness check, we use the four types as individual observations.

The data on the newly registered number of apprenticeships started per occupation comes from the FSO. Every apprentice-independent of starting a dual or a full-time schooling apprenticeship-has to be registered at the respective cantonal authority. The cantonal authorities then deliver their data to the FSO. This data is available only from 2010 to 2017. Before 2010, the data per occupation was collected only at the federal level (not the cantonal), meaning that we cannot calculate the cantonal requirements profile for years before 2010 .

As Table 4 in the Appendix shows, the means of the four different types of requirements are very different, and the variation within the different types is larger than the variation of overall academic requirements profile. At the level of the individual occupations, the most demanding occupation (with 63.19 points) is laboratory technician in physics and the least demanding occupation (with 13.89 points) is shoe repairer.

Of the 236 apprenticeship occupations that currently exist in Switzerland (SKBFCSRE 2018), 161 received an expert rating for the academic requirements. Those 161

\footnotetext{
7 Although experts developed the measure of academic requirements only for dual apprenticeships, one can reasonably assume, for at least two reasons, that the ratings also hold for school-based apprenticeships. First, the ratings apply to the school part of dual VET. Second, given that the final exams are the same and lead to the same diploma, the academic requirements for dual and school-based apprenticeships have to be comparable.

8 We thank Walter Götze (project manager, "Academic requirement profiles for the school part of dual apprenticeships") for providing us with the detailed values of the academic requirements profiles for the majority of all existing apprenticeship occupations.
} 
occupations cover between 62.31 and $85.31 \%$ of all apprenticeship positions, depending on the canton and the year. ${ }^{9}$ To increase the coverage, we imputed most missing values for the academic requirements profile by using a combination of the duration of the apprenticeship by occupation (as suggested by Mueller 2016) and an older but less detailed measure for the academic requirements of an occupation (developed by Stalder 2011). ${ }^{10}$ We imputed values only for the overall academic requirements profile, because Stalder's (2011) older measure does not distinguish between different types and is therefore not precise enough for imputing at a more detailed level. With the imputations, we reach a coverage of between 91.65 and $95.44 \%$.

The average cantonal requirements profile captures the average level of academic requirements of the filled apprenticeship positions in a respective canton. This measure can be interpreted as a proxy for companies' reactions and therefore it should be possible to observe changes in this measure in case companies adapt their behavior to changing external influences as, e.g. changes in academic education rates.

\section{Cantonal success rates in VET}

The cantonal success rate in VET is defined as the percentage of students who took the final exam and passed it. For the analyses, we use both the overall success rate (combination of success rates in dual and school-based apprenticeships), and the success rate for only dual apprenticeships. Due to concerns about anonymity for some small cantons in certain years, the overall success rate is not available, and we therefore had to impute the values. To do so, we calculated the mean of the years before and after the missing year in the respective canton.

As explained in the "Simple model" section, if companies do not adapt their offer of apprenticeship positions in terms of academic requirements (on an aggregated level) to changing rates in academic education, it is obvious that under the assumption of no marked differences in the ability of students at the end of compulsory school between the cantons, a higher percentage of students in academic programs lowers the average educational achievement of those remaining in VET programs. Although this descriptive pattern of correlation can be observed for Switzerland (SKBF-CSRE 2018), a more profound analysis over time and with control variables is necessary to better understand the pattern.

\section{Explanatory variables}

\section{Academic education rate}

The academic education rate is the main explanatory variable of interest in both analyses that we conduct in the "Results" section. In a first step we analyze whether the academic education rate already leads to an adaption of aggregate companies' behavior at the point in time they are filling their apprenticeship positions. The second step-analyzing the relation between the academic education rates and success rates in VET-is then

\footnotetext{
${ }^{9}$ Companies in the different cantons offer both different occupations and different numbers of positions per occupation.

10 Stalder's (2011) measure is not available for all occupations that currently exist in Switzerland. Therefore, we cannot impute the values for the academic requirements for all occupations, and consequently the coverage is not $100 \%$.
} 
necessary to find out whether and if so, how the academic education rate has (negative) consequences for a later point in time, i.e. graduation from VET (success rate in VET).

To measure the academic education rate, we use two different variables. First, we use the cantonal baccalaureate rate, which we call "academic education rate," because the cantonal baccalaureate schools are by far the most important part of upper-secondary academic education. Second, we use an expanded version, in which we also take the graduation rate of upper-secondary specialized schools (Fachmittelschulen) into account, because in addition to academic baccalaureate schools, they count as academic upper-secondary education in Switzerland. We call this expanded version the "alternative academic education rate." (see Table 5 in the Appendix for a comparison of the academic education rate with the alternative academic education rate.)

From 2000 to 2014, the measure for the cantonal baccalaureate rate was a gross quota percentage, defined as the number of students in the typical age of graduation from academic baccalaureate schools (19) who qualified for university entrance (Matura) divided by the permanent resident population at the same age. In 2015, the FSO changed the definition to a net quota percentage, taking an average over three years of all students who graduated from the academic baccalaureate school by age 25 divided by the reference population at the same age. Since we use year dummies in all regressions, the change in the definition, if it has any effect at all, is accounted for in all the regressions. The most recent data is from 2016.

The alternative academic education rate is the sum of the cantonal baccalaureate rate and the cantonal graduation rate from upper-secondary specialized schools. Students who enter an upper-secondary specialized school have on average a competence level (as measured by PISA) comparable to that of students who start an apprenticeship in the top quartile of the academic requirements profile (SKBF-CSRE 2018). Therefore (and again under the assumption that ability is evenly distributed among cantons), we can assume that the higher the percentage of students in upper-secondary specialized schools, the lower the competence level of students in vocational education. However, we do not use this variable in the main specification, because the graduation rate from upper-secondary specialized schools has only been available at the cantonal level since 2011. For the alternative specification in Table 2, we assume the rate to be 0 in 2010, because the overall value for Switzerland was very close to 0 , and we wanted to avoid losing an entire year of observations. Leaving out 2010 does not change the results.

\section{Percentage of school-based VET}

For the percentage of school-based VET, we construct two different variables-entries into and stock of school-based VET-for the different requirements of the different regressions in the "Results" section and describe them in the order we later use them in those regressions. One of the assumptions from the simple model was that if students will always choose academic education and if this is not possible, the most demanding option in VET. It may be that cantons offer more demanding occupations in schoolbased VET compared to companies in dual VET. Therefore, in addition to the academic education rate, we also control for the percentage of school-based VET, as this subtype of education might also draw away students from the other subtype of VET, i.e. dual VET. 
First, to construct the percentage of entries into school-based VET, we use the FSO data on the apprenticeships started and then split them into those who start a dual apprenticeship and those who start a school-based apprenticeship. For each year and canton, we calculate the percentage of school-based apprenticeships by dividing the number of school-based apprenticeships started by the total number of apprenticeships started. In some cantons, the number of school-based apprenticeships grew over the last decade, but other cantons offer no school-based apprenticeships. Although throughout Switzerland the percentage of school-based apprenticeships is lower than $10 \%$, the variation between the cantons is very large, with cantonal averages between 0 and $47.02 \%$ (over the observation period from 2010 to 2016). We call this variable "percentage of school-based VET (entries)," as it covers the entries into school-based apprenticeships per year. As we also constructed the measure for the average cantonal requirements profile with the entries into VET (per occupation), we use the entries into school-based VET as explanatory variable in the respective regressions in the "Main results" section.

Second, to construct the percentage of the stock of school-based VET, while we use the same equation as that for the percentage of entries into school-based VET, we use the stock of students in all years of the apprenticeship. The stock captures the mean percentage of school-based VET over 3-4 years (duration of school-based VET) in a canton. We call this variable the "percentage of school-based VET (stock)" and use it for the regressions on the success rates in the section "Overall success rate in VET and success rate in dual VET as dependent variables". We do so for two reasons. First, entries into school-based VET should only have an impact on the success rates 3 to 4 years later, at the end of the apprenticeship, and we would therefore have to introduce lags. Using lags would lead to fewer observations, because data on entries is not available for the period before 2010 and in turn would make the estimates less precise. Second, the stock of school-based VET is a mean of entries into existing apprenticeship(s), thereby capturing the situation over several years and constituting a more balanced measure, one less prone to outliers.

\section{Percentage of immigrants}

The percentage of immigrants per canton is defined as that of immigrants divided by the permanent resident population per canton. Related literature (Wolter and Zumbuehl 2017) shows, that immigrants typically have different tastes and aspirations, preferring academic to vocational education. If they choose VET, they choose occupations with a higher level of academic requirements than do native-born Swiss and have significantly lower success rates in both, academic and vocational upper-secondary education (SKBFCSRE 2018). Due to those differences in the choice behavior between immigrants and native-born Swiss and the great variation in the percentages of immigrants across the cantons, we expect that this variable might particularly influence the success rates in VET and potentially also on the average cantonal requirements profile in case companies adapt their offer to changing percentages of immigrants. Given that the number of immigrants in Switzerland is high compared to many other countries and varies greatly between the cantons and over time, it is an important control variable. 


\section{Percentage of graduates from compulsory education}

The typical age of graduating from compulsory education in Switzerland is 16. We follow Mühlemann et al. (2009) and Lüthi and Wolter (2020) who show that the population of graduates from compulsory education has a positive impact on the number of new apprenticeship positions. Although we do not analyze the number of apprenticeship positions, but the cantonal composition of apprenticeships in terms of academic requirements, demographic variables might also play a role in the context of those analyses. We take the number of 16-year-old students relative to the entire population per canton as a proxy of graduates from compulsory school and thereby account for cantonal differences in the relative number of graduates of compulsory education. In cantons with a higher percentage of graduates from compulsory education, there is also a higher demand for upper-secondary education, a demand the education system must satisfy. ${ }^{11}$

\section{Percentage of employees in different sectors}

We construct the percentage of employees in different sectors by dividing the number of employees in different sectors by the total number of employees per canton. We use these variables to control for differences in the industry structure of the different cantons and the concomitant differences in the supply of occupations with potentially different levels of academic requirements. We use the General Classification of Economic Activities (NOGA), which contains the number of employees for 99 different sectors and aggregate them to eight broader sectors: Agriculture, Production, Construction, Retail, Financial Services and Insurance, Other Services, Public Administration and Education, and Health. As the number of employees per sector had only been collected every three years before 2011, this annual data is available only from 2011 to $2016 .^{12}$

\section{Results}

To empirically test the predictions we derived from the simple model, we follow a twostep procedure. In a first step, we test whether companies react to differences in the academic education rates across the cantons by analyzing changes in the average cantonal requirements profile. In addition, we test the robustness of the results. We do so, to find out whether at this point in time (apprenticeship positions just filled) a problem is already be visible. By problem we mean a non-adjustment of the companies' offer in average academic requirements which then creates mismatches on an individual level (because more able students go to academic education) that are likely to translate to the next point in time, i.e. the final exams at end of the apprenticeship. In a second step, we then look at what happens at the end of the apprenticeship to see if the non-reaction of companies leading to mismatches between the requirements of the apprenticeship and

\footnotetext{
${ }^{11}$ It might either be, that a changing percentages of compulsory education graduates not only influence the number of positions (Muehlemann et al. 2009; Luethi and Wolter 2020) but also the composition of training positions filled (regression in the "Main results" section) or that even if this is not the case, this demographic variable might have an additional effect on success rate depending on which part of the education system absorbs a growing or falling number of compulsory education graduates and on the quality of the matches (regression in the "Overall success rate in VET and success rate in dual VET as dependent variables" section).

12 We use this control variable in the "Main results" section only, because there might be an influence of changes in the industry structure in the different cantons on the composition of apprenticeships if e.g. industries offering apprenticeships with higher academic requirements expand more than in other industries. However, we do not use the industry structure as control variable for the second regression in the "Overall success rate in VET and success rate in dual VET as dependent variables" section, as it is not clear why we should assume a direct connection between changes in the industry structure on changes in the success rate in VET.
} 
the student's initial skills, translates into a problem at that later point in time. We analyze whether the observed correlation between the academic education rate and the success rate in VET holds over time-expanding the analyses in SKBF-CSRE $(2014,2018)$-and after adding control variables. All regressions shown are weighted by the average population size of the respective canton.

\section{Main results}

In Table 1, column 1, we regress the average academic requirements profile in VET on the academic education rate; the cantonal percentages of immigrants, of schoolbased VET, and of graduates from compulsory education; and other control variables. We find no significant association between changes in the academic education rate and changes in the average cantonal requirements profile. However, we find a positive association between the percentage of school-based VET (entries) and the average requirements profile. If the percentage of school-based VET increases by 10 p.p., the measure for academic requirements would increase by 0.21 points. When adding additional controls for the cantonal industry structure, we lose one year of observations due to data availability, but the effects do not change: The academic education rate is not significant, the percentage of school-based VET remains highly significant, and the effect size increases to 0.33 points.

The interpretation of the results requires the consideration of two findings. First, the results show that the academic education rate does not influence the average requirements profile in VET. This finding suggests that companies react to increases in the academic education rate in their region by filling positions with relatively less able students. Second, however, another variable increases the academic requirements profile, i.e. the percentage of school-based VET, a variable closely connected to the interpretation of the effect of the academic education rate. Cantons appear to raise their academic requirements profile by creating more school-based VET offers in occupations that are more demanding than the cantonal average. This finding in combination with the non-significant effect of the academic education rate suggests that we cannot clearly confirm whether companies react to changes in the academic education rate or not. On one hand, companies may fill their positions with relatively less able students, and cantons may simultaneously create highly demanding schoolbased apprenticeships. On the other hand, companies may react by ceasing to offer highly demanding apprenticeships, while cantons overcompensate for this effect by offering even more highly demanding apprenticeships. As both explanations are possible and could explain the results and as we cannot disentangle the effects, at this step of the analysis we cannot clearly say whether and if so, how companies react to changes in the academic education rates. 
Table 1 Random effects estimations-dependent variable: average cantonal requirements profile in chosen VET occupations (mean: 37.80 ; sd within: 0.39)

\begin{tabular}{|c|c|c|}
\hline Variables & $\begin{array}{l}\text { (1) } \\
\text { Without industry controls }\end{array}$ & $\begin{array}{l}\text { (2) } \\
\text { With industry controls }\end{array}$ \\
\hline \multirow[t]{2}{*}{ Academic education rate } & 2.476 & 1.765 \\
\hline & $(2.171)$ & $(2.448)$ \\
\hline \multirow[t]{2}{*}{ Percentage of immigrants } & 2.038 & -1.351 \\
\hline & $(2.248)$ & $(4.039)$ \\
\hline \multirow[t]{2}{*}{ Percentage of school-based VET (entries) } & $2.140^{* *}$ & $3.314^{* * *}$ \\
\hline & $(0.874)$ & $(0.973)$ \\
\hline \multirow{2}{*}{ Percentage of graduates from compulsory school } & 60.45 & 7.139 \\
\hline & $(77.49)$ & $(106.1)$ \\
\hline \multirow[t]{2}{*}{ Percentage of employees in agriculture } & & 3.350 \\
\hline & & $(17.66)$ \\
\hline \multirow[t]{2}{*}{ Percentage of employees in production } & & 0.674 \\
\hline & & $(10.27)$ \\
\hline \multirow[t]{2}{*}{ Percentage of employees in other services } & & -5.864 \\
\hline & & $(10.65)$ \\
\hline \multirow[t]{2}{*}{ Percentage of employees in construction } & & -7.942 \\
\hline & & $(13.61)$ \\
\hline \multirow[t]{2}{*}{ Percentage of employees in retail } & & 13.27 \\
\hline & & $(11.39)$ \\
\hline \multirow{2}{*}{$\begin{array}{l}\text { Percentage of employees in financial services and insur- } \\
\text { ance }\end{array}$} & & 17.30 \\
\hline & & $(11.71)$ \\
\hline \multirow{2}{*}{$\begin{array}{l}\text { Percentage of employees in public administration and } \\
\text { education }\end{array}$} & & -0.785 \\
\hline & & $(15.86)$ \\
\hline \multirow[t]{2}{*}{ Constant } & $34.75^{* * *}$ & $35.77^{* * *}$ \\
\hline & $(1.301)$ & $(9.066)$ \\
\hline Language region & Yes & Yes \\
\hline Percentage of imputed values & Yes & Yes \\
\hline Year dummies & Yes & Yes \\
\hline Observations & 182 & 156 \\
\hline$R^{2}$ & 0.278 & 0.292 \\
\hline Number of cantons & 26 & 26 \\
\hline
\end{tabular}

This table shows coefficients from a random effects regression. Standard errors in parentheses. Significance levels: *** $p<0.01, * * p<0.05,{ }^{*} p<0.1$. The reference category for the share of employees in the different sectors is the health sector To show that the results are not driven by outliers, two different bivariate illustrations of the relationships between the average cantonal requirements profile and the academic education rate, as well as the percentage of school-based VET appear in Appendix A, Figs. 3 and 4

We additionally tested these regressions with FE models, with very similar results

In Table 2, we replicate the specifications from Table 1 but use the alternative academic education rate, as described in the "Explanatory variables" section, with the graduation rate of upper-secondary specialized schools added to the cantonal baccalaureate rate. Uppersecondary specialized schools may also shift away students from vocational education and therefore potentially change the average requirements profile as explained in the "Explanatory variables" section. The results are similar, and the alternative academic education rate is not significantly correlated with the average cantonal requirements profile in VET. In addition, the highly significant effect of the percentage of school-based VET is also robust. We therefore still cannot confirm whether or, if so, how companies react. However, cantons appear to react by offering school-based VET options that are more demanding than the current average in the canton, thereby increasing the average requirements profile. 
Table 2 Random effects estimations-dependent variable: average cantonal requirements profile in chosen VET occupations, using alternative academic education rate as explanatory variable

\begin{tabular}{|c|c|c|}
\hline \multirow[t]{2}{*}{ Variables } & \multirow{2}{*}{$\begin{array}{l}\text { (1) } \\
\text { Without industry controls }\end{array}$} & \multirow{2}{*}{$\begin{array}{l}\text { (2) } \\
\text { With industry controls }\end{array}$} \\
\hline & & \\
\hline \multirow[t]{2}{*}{ Alternative academic education rate } & -0.335 & -0.469 \\
\hline & $(1.707)$ & $(2.211)$ \\
\hline \multirow[t]{2}{*}{ Percentage of immigrants } & 2.644 & -1.207 \\
\hline & $(2.246)$ & $(4.012)$ \\
\hline \multirow[t]{2}{*}{ Percentage of school-based VET (entries) } & $2.275^{* * *}$ & $3.406^{* * *}$ \\
\hline & $(0.881)$ & $(0.973)$ \\
\hline \multirow[t]{2}{*}{ Percentage of graduates from compulsory school } & 57.74 & 11.53 \\
\hline & (77.63) & $(106.0)$ \\
\hline \multirow[t]{2}{*}{ Percentage of employees in agriculture } & & 1.490 \\
\hline & & $(17.45)$ \\
\hline \multirow[t]{2}{*}{ Percentage of employees in production } & & 0.241 \\
\hline & & $(10.22)$ \\
\hline \multirow[t]{2}{*}{ Percentage of employees in other services } & & -5.560 \\
\hline & & $(10.60)$ \\
\hline \multirow[t]{2}{*}{ Percentage of employees in construction } & & -7.557 \\
\hline & & $(13.56)$ \\
\hline \multirow[t]{2}{*}{ Percentage of employees in retail } & & 12.02 \\
\hline & & $(11.33)$ \\
\hline \multirow{2}{*}{$\begin{array}{l}\text { Percentage of employees in financial services and insur- } \\
\text { ance }\end{array}$} & & 16.26 \\
\hline & & $(11.60)$ \\
\hline \multirow{2}{*}{$\begin{array}{l}\text { Percentage of employees in public administration and } \\
\text { education }\end{array}$} & & -0.649 \\
\hline & & $(15.83)$ \\
\hline \multirow[t]{2}{*}{ Constant } & $35.24^{* * *}$ & $36.41^{* * *}$ \\
\hline & $(1.279)$ & $(9.042)$ \\
\hline Language region & Yes & Yes \\
\hline Percentage of imputed values & Yes & Yes \\
\hline Year dummies & Yes & Yes \\
\hline Observations & 182 & 156 \\
\hline$R^{2}$ & 0.269 & 0.287 \\
\hline Number of cantons & 26 & 26 \\
\hline
\end{tabular}

This table shows coefficients from a random effects regression. Standard errors in parentheses. Significance levels: *** $p<0.01,{ }^{* *} p<0.05,{ }^{*} p<0.1$. The reference category for the share of employees in the different sectors is the health sector We additionally tested these regressions with FE models, with very similar results

In a robustness check (see Table 5 in the Appendix), we replicate Tables 1 and 2 but use an alternative version of the dependent variable. We pool the data and treat each type of the academic requirements profile (language, mathematics, science and foreign languages) as an individual observation per canton. This allows us to make use of the four different types and to have more variation in the dependent variable and therefore increase the precision of the estimates with the higher number of observations. All results are robust to the alternative dependent variable: In none of the specifications is the (alternative) academic education rate significant, and the effect of the percentage of school-based VET remains highly significant. 
Table 3 Random Effects estimations: Overall success rates in VET and success rates in dual VET

\begin{tabular}{lll}
\hline Variables & $\mathbf{( 1 )}$ & $\mathbf{( 2 )}$ \\
& Overall success rate in VET & Success rate in dual VET \\
\hline Academic education rate & $-0.227^{* *}$ & $-0.218^{* *}$ \\
& $(0.0941)$ & $(0.105)$ \\
Percentage of immigrants & $-0.304^{* * *}$ & $-0.310^{* * *}$ \\
& $(0.0675)$ & $(0.0781)$ \\
Percentage of school-based VET (stock) & -0.0325 & -0.0435 \\
& $(0.0366)$ & $(0.0410)$ \\
Percentage of graduates from compulsory school & 0.732 & 2.474 \\
& $(3.161)$ & $(3.566)$ \\
Constant & $1.011^{* * *}$ & $0.989^{* * *}$ \\
& $(0.0430)$ & $(0.0483)$ \\
Year dummies & Yes & Yes \\
Observations & 182 & 182 \\
Number of cantons & 26 & 26 \\
\hline
\end{tabular}

This table shows coefficients from a random effects regression. Significance levels: ${ }^{* *} p<0.01,{ }^{* *} p<0.05,{ }^{*} p<0.1$

To show that the results are not driven by outliers, two different bivariate illustrations of the relationships between the overall success rate in VET and the academic education rate, as well as between the success rate in dual VET and the academic education rate appear in the Appendix A, Figs. 5 and 6

We also tested, if the average cantonal requirements profile in VET is associated with the overall success rate in VET and the success rate in dual VET (same specifications as Table 3, column 1 and column 2). A direct relationship between the two variables is not ex ante clear, because a constant average cantonal requirements profile would only point into the direction of more mismatches between students' ability and requirements of the occupation that as a consequence translate into a lower success rate in VET. As the relationship is not significant and very small in size, we do not show it in Table 3

\section{Overall success rate in VET and success rate in dual VET as dependent variables}

Given that we do not find an adjustment in the average cantonal requirements profile of chosen occupations to changes in the rate of academic education, we now test whether changes in academic education rates are associated to changes at a later point in time, i.e. success rates in VET and test whether the correlation between the success rate in VET and the academic education rate (SKBF-CSRE 2018) holds (a) over time and (b) with the introduction of control variables.

Table 3, column 1, shows the specification with the overall success rate in VET as the dependent variable, and column 2 shows the results for the success rate only in dual VET. In column 1 , we see that the academic education rate correlates significantly and negatively with the overall success rate in VET. An increase in the academic education rate by 10 p.p. would translate into a decrease of 2.27 p.p. in the overall success rate in VET. For the success rate in dual VET, the effect goes in the same direction and is of similar size. A change in the academic education rate by 10 p.p. would translate into a decrease of 2.18 p.p. in the success rate in dual VET. Taking those two results together suggests, that we can confirm the observation that increasing academic education rates are negatively correlated with both the overall success rate in VET and the success rates in dual VET. ${ }^{13}$

The cantonal percentage of immigrants is highly significant in both columns. If that percentage grew by 10 p.p., the overall success rate in VET would decrease by 3.04 p.p. and 3.1 p.p. for the success rate in dual VET. This strong, negative association

\footnotetext{
${ }^{13}$ The results are robust to the exclusion of single cantons in the regressions. The effect of the academic education rate remains negative and significant in all but one case (Zurich), where the effect is still negative but not statistically significant.
} 
is not surprising, given the strong differences between immigrants and native-born Swiss in success rates in upper-secondary education in general (SKBF-CSRE 2018, graph 105). A likely explanation for this strong negative association appears in Wolter and Zumbuehl (2017). Using the SEATS dataset, ${ }^{14}$ they find evidence for different tastes and aspirations of immigrants, resulting in the choice of more demanding educational tracks and occupations, a choice later translating into higher failure rates.

While we find that the average cantonal requirements profile is not responsive to the academic education rate, it is positively related to the share of school-based VET. In school-based VET it is not the employers who decide whether a candidate gets a training position, but the respective cantonal VET school. In other words, it is likely that students who would not have been offered a training position from an employer because the academic requirements are higher than what they bring along, still find a full-time VET school that accept them. Seen in this light it is surprising that the share of full-time VET has no impact on the failure rates at the final VET exams, as by law the schools should use the same exam standards as dual apprenticeships in the same occupation. However, it could also mean that although written in the law, final exams are not exactly the same for full-time and dual VET. This would be an important question to follow up in future research to better understand the underlying mechanisms.

Coming back to the research question and the predictions from the simple model, we can summarize and interpret the results as follows: For the main prediction (P1), we observe that a regional increase in academic education is associated with a decrease in the overall success rate in VET and in the success rate in dual VET, but not with changes in the average cantonal requirements profile. For the ancillary prediction (P2), we find support that there is additionally a negative relationship between the percentage of school-based VET and the overall and success rate in dual VET, the coefficients are, however, not statistically significant. As we cannot clearly disentangle the reactions of companies and cantons, this finding suggests, that there is no clear evidence on whether the lower average ability in VET in cantons with higher academic education rates is borne by the companies or by the cantons, or both. Overall and interpreting the results from the two parts of the analysis together ("Main results" and "Overall success rate in VET and success rate in dual VET as dependent variables" sections), the findings point towards academic education drawing away highly-able students from vocational education with negative consequences for the success rates in VET.

\section{Limitations of the results}

Although the results give first important insights and many ideas for future research, they have to be interpreted with caution for several reasons. One of the main limitations of the analyses in this paper is the small number of observations due to the (given) small number of cantons in Switzerland in combination with data availability for only a limited number of years. Even though we tested different specifications (as documented in footnotes and/ or the appendix), this means also that we can only use a limited number of control variables for the main specifications. This brings us to the next point, i.e. potential biases due

14 The SEATS (Swiss Educational Attainment and Transition Study) dataset consists of all 9th graders who took the PISA 2012 test and follows students into upper-secondary education through a link with register data. 
to omitted variables. Although we are convinced that we are able to control for the most important variables at this aggregated level, there are several minor factors that we cannot account for. Coming back to the simple model, one variable that could potentially have an influence on success rates in VET and challenge our assumption that ability is the same over all cantons, is the average ability per canton. In the absence of a yearly and representative standardized external assessment of student ability in Switzerland, building cantonal averages of the competence measures from the data of the PISA tests 2012 and 2015 would be an option. However, this data is only available for the two years mentioned and even more important, the data for 2012 is representative for Switzerland as a whole, but not for every canton (Zumbuehl and Wolter 2017), which would introduce a bias into an unknown direction. In addition, the data from 2015 is not comparable to the data from 2012, among others, because the survey method was changed (paper- to computer-based) which introduced an unratable change (Konsortium PISA.ch 2018). Although it would be better to test this directly, in summary, we think that our assumption that ability does not differ between the different cantons is plausible, potential differences are accounted for by the other control variables we use and it does not cause any bias.

In this paper, with the data we have, we can only proxy companies' reactions by constructing the average cantonal requirements profile. Although using the filled apprenticeship positions captures how companies decided in the end, to fully understand what is going on in terms of decision-making processes and reasoning, it would additionally be necessary to have data on all apprenticeship vacancies posted, and application data of students. However, this data has unfortunately so far not been collected in Switzerland (Luethi and Wolter 2020). This additional data in combination with individual data on student behavior, ability, motivation, non-cognitive skills and student and family background, would however be necessary to better understand who reacts in which way and why and what this ultimately means for the success rates in VET.

In the absence of an external shock as e.g. in Germany with reduction of the years of schooling in some states (Muehlemann et al. 2018), we cannot claim causality for our results. Even though the interdependencies studied in this paper are quite complex, we can at least provide some arguments why reversed causality should not be an issue. The academic education rate is the result of political decisions that are driven by different and partly unknown factors within the cantons, that do not necessarily have to do with the needs of the economy. Therefore, it is also very unlikely that companies or professional associations have the power to influence the academic education rate in a significant way, have to take the situation as given and could potentially adapt their offer. If they do not do that, they will also have to bear the costs later, i.e. lower success rates in VET. In addition, companies can generally be seen as more flexible to adapt to changes, because they have to survive on the market but actions or decisions by the state and schools are not (always) guided by market or competition considerations. An additional argument to underpin this is that academic education (in Switzerland) does not react to business cycles (Muehlemann et al. 2009). In summary, all the arguments given point into the direction that the academic education rate and also the percentage of school-based VET influence the index and the success rate in VET, and not the other way around. 


\section{Conclusions and discussion}

In this paper, we analyze the interplay between academic and vocational education at the upper-secondary level and the consequences thereof. In a first step, we analyze the reaction of companies - the main provider of vocational education - to differences in academic education rates. To do so, we construct a measure of the average requirements profile per canton to discover whether companies adapt their supply of highly demanding apprenticeships in response to increasing academic education rates. In a second step, we analyze whether the academic education rate is associated with the success rates in VET.

For the first part of the analysis, we find the following: The first finding is that the academic education rate does not correlate significantly with the average cantonal requirements profile in VET. This finding indicates that companies do not react to the changes in academic education rates but instead fill their positions with students situated at a lower part of the ability distribution. However, the second finding puts this interpretation of the first finding into perspective by showing that the percentage of school-based VET, which is set by the cantons, increases the average cantonal requirements profile. This second finding indicates that cantons create school-based apprenticeship positions mainly in occupations that are more demanding than the cantonal average. As for the reaction or non-reaction of companies to different academic education rates in the different cantons, two possibilities could underlie this finding. First, the results may suggest both that (a) companies fill their positions with less able students and (b) cantons create school-based positions in occupations that are more demanding than the average cantonal requirements profile at the same time. Second, however, companies may react by no longer offering highly demanding positions while cantons overcompensate for that reaction by offering even more school-based VET in occupations that are more demanding than the average in the canton. Thus, we cannot clearly conclude from our analyses whether companies react or not to changes in academic education rates.

Although the finding that the percentage of school-based VET increases the average requirements profile might not appear important at first glance, at least four reasons indicate that this relationship might raise concerns. First, since the 2000s, an oversupply of dual apprenticeship positions has existed. Consequently, from a quantitative point of view, there is no need for expanding school-based VET, even though such an expansion is visible in the data used in this paper and also described in SKBF-CSRE (2018). Second, school-based VET makes sense in situations where companies in promising occupations are not (yet) able to offer enough positions. However, the large differences between the cantons and the large growth of the percentages of school-based VET in some cantons brings into question whether offering promising occupations not offered by companies is the only reason for the cantons to offer school-based VET (SKBF-CSRE 2018).

Third, the expansion of school-based VET is much more costly for the cantons than dual VET (SKBF-CSRE 2018). This development raises doubts in terms of efficiency, i.e., cantons should think carefully about costs and benefits when expanding 
school-based VET. This third reason is connected to a fourth point: the labor market outcomes of graduates from school-based VET. Although thus far there is no evidence for the differences in labor market outcomes for graduates from dual and school-based VET within Switzerland, Bolli et al. (2017) show for an international sample that school-based VET and academic education in comparison to dual VET negatively influence the transition of young people to the labor market. If those results also hold true for the differences within Switzerland, this would have at least two important implications for policy makers. First, rising public spending for school-based VET would come into question if dual VET is better able to smoothen the transition to the labor market and enough positions are available. Second, cantons also have to bear the costs for academic education that are increasing with rising academic education rates. Taking those two considerations together could lead to a downward spiral of rising costs for cantons with rising rates of school-based VET and academic education on upper-secondary level. An additional point that would need to be taken into account and careful monitoring is the interplay between the two types of vocational education, i.e. dual and school-based VET, in competing for highly-able students.

In the second part of the analysis, we find a negative correlation between the academic education rate and the overall success rate in VET, as well as for the success rate in dual VET. The findings indicate that changes in the academic education rate produce a situation where highly-able students are drawn away from vocational education resulting in positions in VET being filled with less able students, and later translating into a lower overall success rate in VET and lower success rate in dual VET. Although we do not find a significant effect of the differences in the percentage of school-based VET itself on the success rates in VET, Bolli et al. (2017) show for an international sample that the differences may have a negative influence on the subsequent step, the transition to the labor market.

Future research should therefore replicate the analyses done for several countries by Bolli et al. (2017) for Switzerland at the cantonal level making use of the variation across cantons in academic education rates, to test whether the negative consequences of the percentage of school-based VET for the labor market transition also hold within Switzerland. In addition, taking a closer look at the individual level-i.e., whether the type of VET (dual of school-based) can predict drop-out or success in the final exam and labor market success-is also important for future research.

Another robust finding from the second part of the analysis is that the percentage of immigrants per canton negatively correlates with the overall success rate and the success rate in dual VET. This finding is not surprising, given the observed differences in success rates in upper-secondary education between immigrants and native-born Swiss (BFS 2018; SKBF-CSRE 2018). The observed differences can be explained by immigrants' different tastes and aspirations for academic education and occupations with high academic requirements, combined with an information deficit (particularly about VET) that ultimately translates into lower success rates. 
To tackle this problem and help immigrants attain a higher success rate in VET, an important first step is to better understand why immigrants and native-born Swiss differ in their tastes and aspirations (Wolter and Zumbuehl 2017). In a second step, an information experiment inspired by Goux et al. (2017) would help to discover whether the information gap between immigrants and native-born Swiss can be closed by giving immigrants more targeted information about vocational education. Goux et al. (2017) show that a series of individual information sessions can help students develop more realistic plans, resulting in lower grade repetition and drop-out rates. In times of rising percentages of students of immigrant descent in many countries (Wolter and Zumbuehl 2017), analyzing differences in tastes and aspirations as early as possible-to avoid inefficiencies in later choices-is critical.

The results of this paper are relevant not only for Switzerland but also for countries that (a) have an academic and a vocational part in their education system or (b) want to introduce a (dual) vocational education. In terms of the long-term educational goal of having 95\% of young people (through age 25) graduate from upper-secondary education in Switzerland (EDK 2015), our analyses help better explain the reasons for the lack of success thus far (BFS 2018). Although we do not claim causality for our results, the analyses provide a more complete picture than mere descriptive evidence and offer ideas for further research in this area. Maximizing graduation rates in upper-secondary education should also be an important goal for other countries, as it would ensure access to both the labor market and tertiary education. Not only countries with two types of education but also those wanting to introduce (dual) vocational education need to keep in mind the interplay between academic and vocational education, if they are to ensure a constant quality and prestige of both types for meeting current and future labor market needs. In addition to the interplay between academic and vocational education, countries that have different types of vocational education in their education system also need to carefully analyze the interplay between dual and school-based vocational education and the consequences of this interaction.

Given the national standardization of diplomas in VET, we focused our analysis on the consequences of increasing academic education rates for vocational education, an analysis on upper-secondary level only. However, focusing on the interplay of different types of education on the same educational level is not sufficient to understand the overall picture of interrelations in the education system. Therefore, our analyses fit in between two strands of the literature in terms of implications and complete them. First, Backes-Gellner and Weckmüller (1998) and Backes-Gellner and Veen (2008) theoretically and empirically demonstrate the importance of the interplay between lower- and upper-secondary education and show that central exams in upper-secondary academic education are a means of quality assurance. Their findings have important implications for the Swiss case analyzed in this paper. To stop the continuing drawing away of highly-able students from vocational to academic uppersecondary education and to improve resulting lower success rates in VET, central exams for 
entering into the counterpart, i.e. academic education, should be introduced. Central exams do not only improve the overall quality of education and even economic growth (see, e.g., Woessmann 2018), but also have a positive impact on individual outcomes such as achievement, wages and employment. The question of whether central exams in academic education should be introduced is a political one eventually, and a question that is highly debated in Switzerland. Our analyzes show however that the differences in the academic education rates seem to be harmful and the economic literature on central exams provides consistent findings pointing into the direction of positive impacts of central exams on several outcomes.

Second, research evidence also suggests that differences in the academic education rates translate into problems at the next educational level, tertiary education. Cantons with higher academic education rates also have higher drop-out rates at the university level (Wolter et al. 2014). This finding shows that analyzing the immediate effects of the interplay between academic and vocational education is only a first step: If future research is to tackle systemic problems, as well as fully understand and explain them, it must also keep in mind the potential effects at the preceding and the subsequent educational level.

As previously stated, all results in this paper have to be interpreted with some caution. In the absence of exogenous variation or shocks, we are not able to identify causal effects. In addition, the number of observations is naturally limited, and the number of years is limited due to data restrictions. Nevertheless, the results provide first valuable evidence on a topic that, despite being highly important to educational policy makers and researchers, has thus far been overlooked in the literature.

\begin{abstract}
Acknowledgements
I am very grateful to my colleagues Maria Zumbuehl (formerly University of Bern) and Christian Eggenberger (University of Zurich) for their helpful comments and stimulating discussions. I would also like to thank the supervisors of my dissertation Prof. Uschi Backes-Gellner (University of Zurich) and Prof. Stefan C. Wolter (University of Bern) who made this research project possible and gave useful comments. In addition, I would also like to thank the two anonymous reviewers who gave very valuable comments that helped a lot in improving the paper and making it more precise.
\end{abstract}

\title{
Authors' contributions
}

The author read and approved the final manuscript.

Funding

This study is funded by the State Secretariat for Education, Research and Innovation (SERI) through its Leading House on the Economics of Education, Firm Behaviour and Training Policies (Grant No. 1315000868). This paper was written while Katharina Jaik was a visiting researcher at the University of Bern.

\section{Availability of data and materials}

Almost all data used for this paper is publicly available at the website of the Swiss Federal Statistical Office (FSO) https ://www.bfs.admin.ch/bfs/en/home.html. The detailed academic requirement profiles per occupation are available upon request for research purposes from http://www.anforderungsprofile.ch.

Competing interests

The author declares that they have no competing interests.

\section{Appendix}

\section{Appendix A}

See Tables 4, 5 and Figs. 3, 4, 5 and 6 
Table 4 Descriptive statistics (2010-2016; 2011-2016 for percentages of employees per sector)

\begin{tabular}{|c|c|c|c|c|c|}
\hline Variable & Mean & Std. Dev & Min & Max & Observations \\
\hline \multicolumn{6}{|c|}{ Average requirements profile } \\
\hline Overall & 37.77958 & 0.718916 & 36.15791 & 40.22382 & $N=182$ \\
\hline Between & & 0.6202714 & 36.67223 & 39.52893 & $n=26$ \\
\hline Within & & 0.3806011 & 36.5047 & 38.98127 & $T=7$ \\
\hline \multicolumn{6}{|c|}{ Academic requirements in language } \\
\hline Overall & 39.48141 & 1.862188 & 32.24052 & 43.65704 & $N=182$ \\
\hline Between & & 1.782228 & 34.21083 & 42.61437 & $n=26$ \\
\hline Within & & 0.6298416 & 36.77589 & 42.31539 & $T=7$ \\
\hline \multicolumn{6}{|c|}{ Academic requirements in mathematics } \\
\hline Overall & 35.28047 & 1.893371 & 29.36918 & 43.88929 & $N=182$ \\
\hline Between & & 1.713335 & 31.31002 & 39.31008 & $n=26$ \\
\hline Within & & 0.864086 & 32.29405 & 39.85969 & $T=7$ \\
\hline \multicolumn{6}{|c|}{ Academic requirements in science } \\
\hline Overall & 39.74382 & 1.683871 & 32.31897 & 43.70227 & $N=182$ \\
\hline Between & & 1.573057 & 34.87237 & 42.25246 & $n=26$ \\
\hline Within & & 0.6655398 & 37.19043 & 42.34876 & $T=7$ \\
\hline \multicolumn{6}{|c|}{ Academic requirements in foreign languages } \\
\hline Overall & 13.34942 & 1.158093 & 10.44164 & 16.71619 & $N=182$ \\
\hline Between & & 1.103755 & 10.97519 & 16.06949 & $n=26$ \\
\hline Within & & 0.4040901 & 12.06212 & 14.6211 & $T=7$ \\
\hline \multicolumn{6}{|c|}{ Overall success rate in VET } \\
\hline Overall & 0.917229 & 0.0384134 & 0.7585523 & 0.973747 & $N=182$ \\
\hline Between & & 0.0369964 & 0.8280754 & 0.9650592 & $n=26$ \\
\hline Within & & 0.012338 & 0.847706 & 0.9600205 & $T=7$ \\
\hline \multicolumn{6}{|c|}{ Success rate in dual VET } \\
\hline Overall & 0.9153385 & 0.0410322 & 0.7445512 & 0.973747 & $N=182$ \\
\hline Between & & 0.039602 & 0.8200028 & 0.9650592 & $n=26$ \\
\hline Within & & 0.0129351 & 0.8398869 & 0.9578846 & $\mathrm{~T}=7$ \\
\hline \multicolumn{6}{|c|}{ Academic education rate } \\
\hline Overall & 0.1946923 & 0.047578 & 0.1082677 & 0.3209726 & $N=182$ \\
\hline Between & & 0.0465394 & 0.1309299 & 0.2963495 & $n=26$ \\
\hline Within & & 0.013021 & 0.1438511 & 0.2423116 & $T=7$ \\
\hline \multicolumn{6}{|c|}{ Alternative academic education rate } \\
\hline Overall & 0.215695 & 0.0565057 & 0.122807 & 0.377293 & $N=182$ \\
\hline Between & & 0.0546714 & 0.1389165 & 0.3396243 & $n=26$ \\
\hline Within & & 0.0174072 & 0.1481207 & 0.2661766 & $T=7$ \\
\hline \multicolumn{6}{|c|}{ Percentage of immigrants } \\
\hline Overall & 0.2136943 & 0.0707061 & 0.0974253 & 0.4094976 & $N=182$ \\
\hline Between & & 0.071356 & 0.1045613 & 0.4005796 & $n=26$ \\
\hline Within & & 0.0087436 & 0.1908044 & 0.2321561 & $T=7$ \\
\hline \multicolumn{6}{|c|}{ Percentage of school-based VET (entries) } \\
\hline Overall & 0.0732393 & 0.1124353 & 0 & 0.4702395 & $N=182$ \\
\hline Between & & 0.1111558 & 0 & 0.3948114 & $n=26$ \\
\hline Within & & 0.0263756 & -0.0247664 & 0.2153434 & $T=7$ \\
\hline \multicolumn{6}{|c|}{ Percentage of school-based VET (stock) } \\
\hline Overall & 0.0824078 & 0.1196379 & 0 & 0.4606203 & $N=182$ \\
\hline Between & & 0.1181228 & 0 & 0.416153 & $n=26$ \\
\hline Within & & 0.0286839 & -0.0279075 & 0.1619444 & $\mathrm{~T}=7$ \\
\hline
\end{tabular}


Table 4 (continued)

\begin{tabular}{|c|c|c|c|c|c|}
\hline Variable & Mean & Std. Dev & Min & Max & Observations \\
\hline \multicolumn{6}{|c|}{ Percentage of graduates from compulsory education } \\
\hline Overall & 0.0109984 & 0.0011317 & 0.0076531 & 0.0146609 & $N=182$ \\
\hline Between & & 0.0010228 & 0.0080837 & 0.0132621 & $n=26$ \\
\hline Within & & 0.0005188 & 0.0091716 & 0.0129377 & $\mathrm{~T}=7$ \\
\hline \multicolumn{6}{|c|}{ Percentage of imputed values (dependent variable) } \\
\hline Overall & 0.1655358 & 0.029066 & 0.0887115 & 0.3107899 & $N=182$ \\
\hline Between & & 0.027446 & 0.1233392 & 0.257132 & $n=26$ \\
\hline Within & & 0.0107944 & 0.1309081 & 0.2191936 & $T=7$ \\
\hline \multicolumn{6}{|c|}{ Percentage of employees in agriculture } \\
\hline Overall & 0.0479598 & 0.028943 & 0.0003199 & 0.138199 & $N=156$ \\
\hline Between & & 0.0293191 & 0.0005028 & 0.129715 & $n=26$ \\
\hline Within & & 0.0024121 & 0.0406212 & 0.0564437 & $T=6$ \\
\hline \multicolumn{6}{|c|}{ Percentage of employees in production } \\
\hline Overall & 0.1660654 & 0.0572611 & 0.0700826 & 0.3032209 & $N=156$ \\
\hline Between & & 0.0573165 & 0.0741173 & 0.2964161 & $n=26$ \\
\hline Within & & 0.0099813 & 0.1277266 & 0.2037565 & $T=6$ \\
\hline \multicolumn{6}{|c|}{ Percentage of employees in other services } \\
\hline Overall & 0.3201441 & 0.052581 & 0.216515 & 0.430584 & $N=156$ \\
\hline Between & & 0.0531009 & 0.2189658 & 0.4255397 & $n=26$ \\
\hline Within & & 0.0060006 & 0.2907029 & 0.3345292 & $\mathrm{~T}=6$ \\
\hline \multicolumn{6}{|c|}{ Percentage of employees in construction } \\
\hline Overall & 0.0799431 & 0.0207528 & 0.0415706 & 0.1315162 & $N=156$ \\
\hline Between & & 0.0209583 & 0.0426848 & 0.1208313 & $n=26$ \\
\hline Within & & 0.0023659 & 0.0687933 & 0.0906279 & $\mathrm{~T}=6$ \\
\hline \multicolumn{6}{|c|}{ Percentage of employees in retail } \\
\hline Overall & 0.1241686 & 0.0215848 & 0.079553 & 0.1975734 & $N=156$ \\
\hline Between & & 0.0216579 & 0.0843819 & 0.1912512 & $n=26$ \\
\hline Within & & 0.0034595 & 0.1141999 & 0.1360938 & $T=6$ \\
\hline \multicolumn{6}{|c|}{ Percentage of employees in financial services and insurance } \\
\hline Overall & 0.0386532 & 0.0193645 & 0.0207549 & 0.0985102 & $N=156$ \\
\hline Between & & 0.0196428 & 0.0214944 & 0.0940751 & $n=26$ \\
\hline Within & & 0.0012616 & 0.03502 & 0.0430883 & $T=6$ \\
\hline \multicolumn{6}{|c|}{ Percentage of employees in public administration and education } \\
\hline Overall & 0.0972419 & 0.0154127 & 0.0667508 & 0.1341347 & $N=156$ \\
\hline Between & & 0.0154025 & 0.071969 & 0.1313856 & $n=26$ \\
\hline Within & & 0.0028225 & 0.0857241 & 0.1070654 & $\mathrm{~T}=6$ \\
\hline \multicolumn{6}{|c|}{ Percentage of employees in Health } \\
\hline Overall & 0.1258239 & 0.0256674 & 0.0688394 & 0.2116868 & $N=156$ \\
\hline Between & & 0.0256936 & 0.0733402 & 0.2050814 & $n=26$ \\
\hline Within & & 0.0044667 & 0.1126382 & 0.1368301 & $T=6$ \\
\hline
\end{tabular}


Table 5 Robustness check: dependent variable split up by the four different types of the academic requirements profile

\begin{tabular}{|c|c|c|c|c|}
\hline \multirow[t]{2}{*}{ Variables } & \multirow{2}{*}{$\begin{array}{l}\text { (1) } \\
\text { Without industry } \\
\text { controls }\end{array}$} & \multirow{2}{*}{$\begin{array}{l}\text { (2) } \\
\text { Without industry } \\
\text { controls }\end{array}$} & \multirow{2}{*}{$\begin{array}{l}\text { (3) } \\
\text { With industry } \\
\text { controls }\end{array}$} & \multirow{2}{*}{$\begin{array}{l}\text { (4) } \\
\text { With industry } \\
\text { controls }\end{array}$} \\
\hline & & & & \\
\hline \multirow{2}{*}{$\begin{array}{l}\text { Academic education } \\
\text { rate }\end{array}$} & -0.832 & & 0.503 & \\
\hline & $(2.141)$ & & $(2.258)$ & \\
\hline \multirow{2}{*}{$\begin{array}{l}\text { Alternative academic } \\
\text { education rate }\end{array}$} & & 0.273 & & 0.387 \\
\hline & & $(1.661)$ & & $(2.033)$ \\
\hline \multirow{2}{*}{$\begin{array}{l}\text { Percentage of immi- } \\
\text { grants }\end{array}$} & -2.645 & -2.910 & -4.374 & -4.371 \\
\hline & $(2.572)$ & $(2.580)$ & $(3.697)$ & $(3.695)$ \\
\hline \multirow{2}{*}{$\begin{array}{l}\text { Percentage of full- } \\
\text { time schooling VET } \\
\text { (entries) }\end{array}$} & $6.493^{* * *}$ & $6.459^{* * *}$ & $6.863^{* * *}$ & $6.856^{* * *}$ \\
\hline & $(0.789)$ & $(0.797)$ & $(0.811)$ & $(0.815)$ \\
\hline \multirow{2}{*}{$\begin{array}{l}\text { Percentage of gradu- } \\
\text { ates from compul- } \\
\text { sory school }\end{array}$} & -97.49 & -99.05 & -117.5 & -116.2 \\
\hline & $(75.47)$ & $(75.48)$ & $(97.17)$ & $(97.02)$ \\
\hline \multirow{2}{*}{$\begin{array}{l}\text { Percentage of employ- } \\
\text { ees in Agriculture }\end{array}$} & & & 12.20 & 12.05 \\
\hline & & & $(16.22)$ & (16.10) \\
\hline \multirow{2}{*}{$\begin{array}{l}\text { Percentage of employ- } \\
\text { ees in production }\end{array}$} & & & 6.961 & 6.932 \\
\hline & & & (9.444) & $(9.427)$ \\
\hline \multirow{2}{*}{$\begin{array}{l}\text { Percentage of employ- } \\
\text { ees in other services }\end{array}$} & & & 1.166 & 1.216 \\
\hline & & & $(9.797)$ & (9.783) \\
\hline \multirow{2}{*}{$\begin{array}{l}\text { Percentage of employ- } \\
\text { ees in construction }\end{array}$} & & & 9.563 & 9.784 \\
\hline & & & (12.49) & $(12.48)$ \\
\hline \multirow{2}{*}{$\begin{array}{l}\text { Percentage of employ- } \\
\text { ees in retail }\end{array}$} & & & $25.08^{* *}$ & $25.02^{* *}$ \\
\hline & & & $(10.41)$ & (10.39) \\
\hline \multirow{2}{*}{$\begin{array}{l}\text { Percentage of employ- } \\
\text { ees in financial } \\
\text { services and insur- } \\
\text { ances }\end{array}$} & & & $21.26^{* *}$ & $21.20^{* *}$ \\
\hline & & & $(10.72)$ & $(10.70)$ \\
\hline \multirow{2}{*}{$\begin{array}{l}\text { Percentage of } \\
\text { employees in public } \\
\text { administration and } \\
\text { education }\end{array}$} & & & -1.648 & -1.438 \\
\hline & & & $(14.58)$ & (14.58) \\
\hline \multirow[t]{2}{*}{ Constant } & $35.08^{* * *}$ & $34.91^{* * *}$ & $28.96^{* * *}$ & $28.93^{* * *}$ \\
\hline & $(1.325)$ & $(1.300)$ & $(8.331)$ & $(8.331)$ \\
\hline $\begin{array}{l}\text { Type of academic } \\
\text { requirements profile } \\
\text { (language, foreign } \\
\text { languages, science) }\end{array}$ & Yes & Yes & Yes & Yes \\
\hline $\begin{array}{l}\text { Language region } \\
\text { dummy }\end{array}$ & Yes & Yes & Yes & Yes \\
\hline Year dummies & Yes & Yes & Yes & Yes \\
\hline Observations & 728 & 728 & 624 & 624 \\
\hline$R^{2}$ & 0.156 & 0.156 & 0.198 & 0.198 \\
\hline $\begin{array}{l}\text { Number of observa- } \\
\text { tions per year }\end{array}$ & 104 & 104 & 104 & 104 \\
\hline
\end{tabular}

This table shows coefficients of a random effects regression. Standard errors in parentheses. Significance levels: *** $p<0.01$, ${ }^{* *} p<0.05,{ }^{*} p<0.1$. The reference category for the share of employees in the different sectors is the health sector and for the type of academic requirements profiles is mathematics 


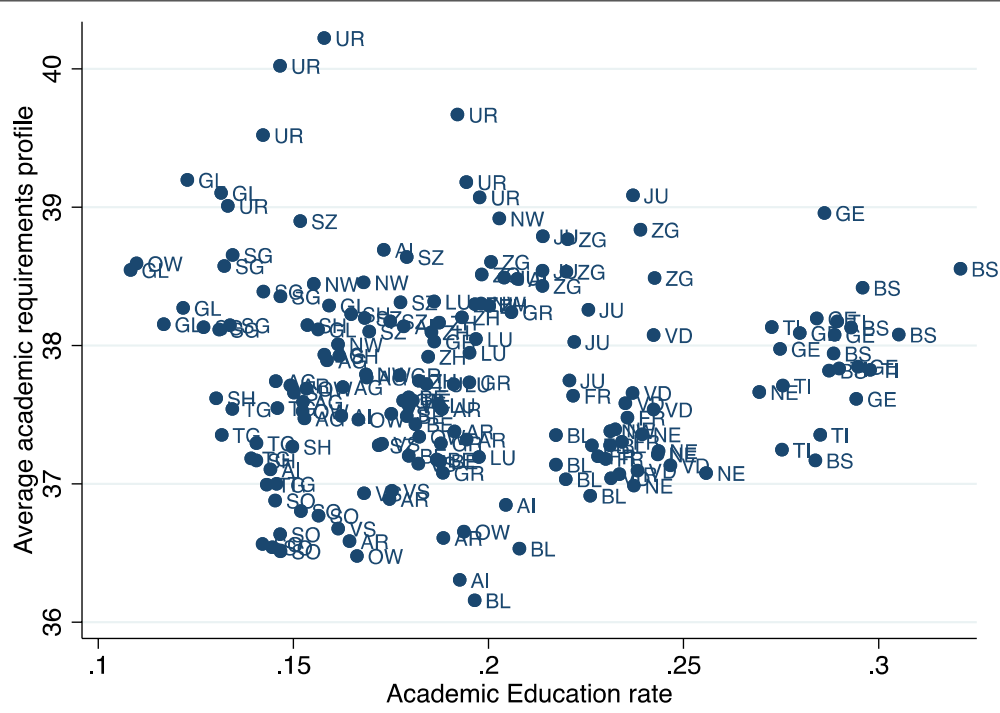

Fig. 3 Correlation between average academic requirements profile and academic education rate 2010-2016, all Swiss cantons. AG Aargau, Al Appenzell Innerrhoden, BL Basel-Landschaft, BS Basel-Stadt, FR Fribourg/Freiburg, GE Genève, GL Glarus, GR Graubünden, JU Jura, LU Luzern, NE Neuchâtel/Neuenburg, NW Nidwalden, OW Obwalden, AR Appenzell Ausserrhoden, BE Bern/Berne, SH Schaffhausen, SO Solothurn, SG St. Gallen, SZ Schwyz, TG Thurgau, TITicino, UR Uri, VD Vaud, VS Valais, ZG Zug, ZH Zürich

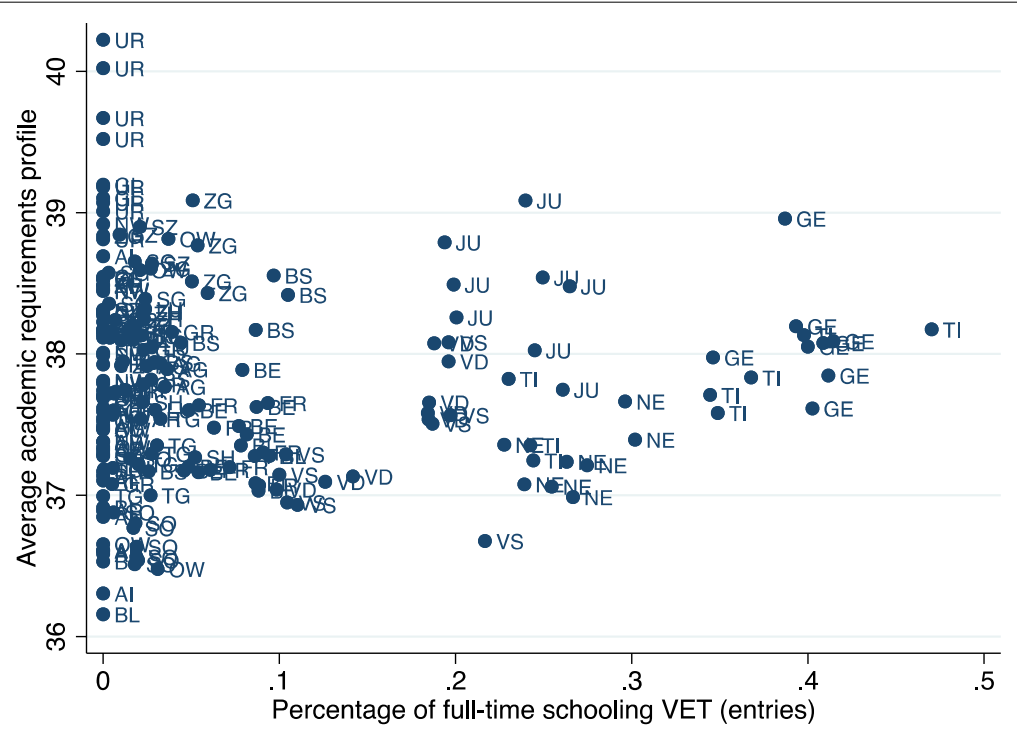

Fig. 4 Correlation between average academic requirements profile and percentage of full-time schooling VET (entries) 2010-2016, all Swiss cantons. AG Aargau, Al Appenzell Innerrhoden, BL Basel-Landschaft, BS Basel-Stadt, FR Fribourg/Freiburg, GE Genève, GL Glarus, GR Graubünden, JU Jura, LU Luzern, NE Neuchâtel/ Neuenburg, NW Nidwalden, OW Obwalden, AR Appenzell Ausserrhoden, BE Bern/Berne, SH Schaffhausen, SO Solothurn, SG St. Gallen, SZ Schwyz, TG Thurgau, TI Ticino, UR Uri, VD Vaud, VS Valais, ZG Zug, ZH Zürich 


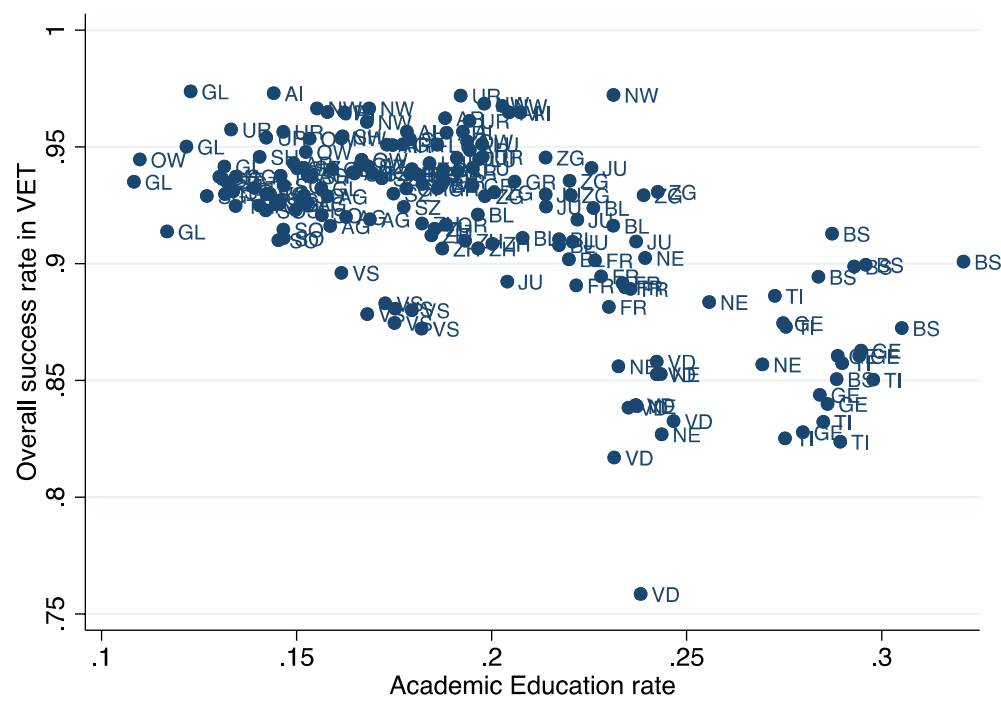

Fig. 5 Correlation between overall success rate in VET and academic education rate 2010-2016, all Swiss cantons. AG Aargau, Al Appenzell Innerrhoden, BL Basel-Landschaft, BS Basel-Stadt, FR Fribourg/Freiburg, GE Genève, GL Glarus, GR Graubünden, JU Jura, LU Luzern, NE Neuchâtel/Neuenburg, NW Nidwalden, OW Obwalden, AR Appenzell Ausserrhoden, BE Bern/Berne, SH Schaffhausen, SO Solothurn, SG St. Gallen, SZ Schwyz, TG Thurgau, TI Ticino, UR Uri, VDVaud, VS Valais, ZG Zug, ZH Zürich

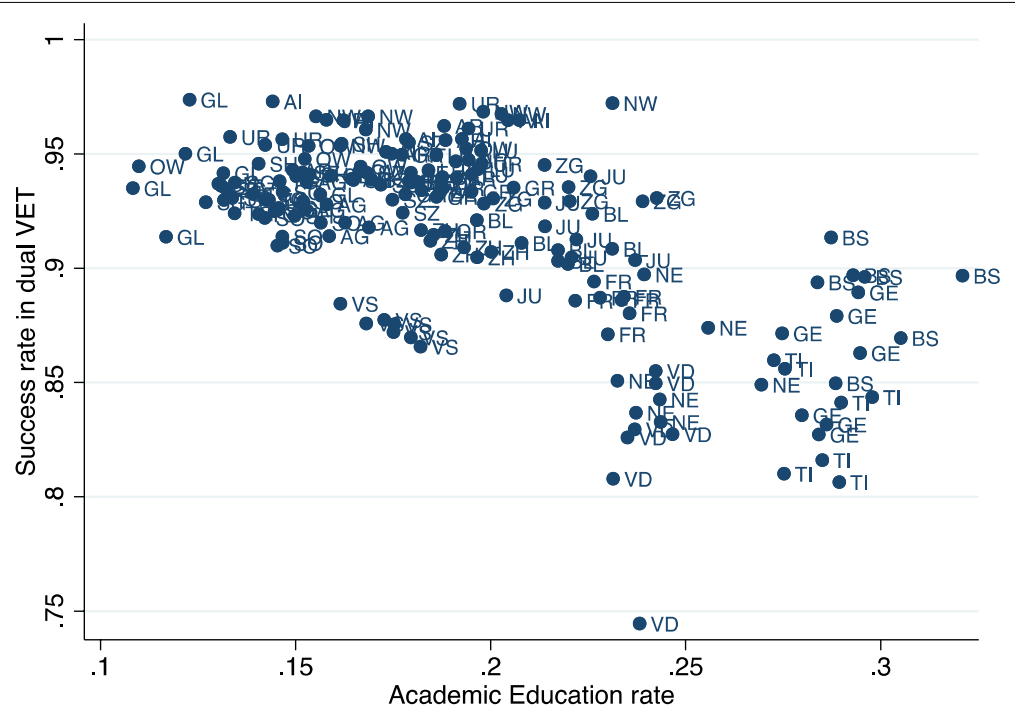

Fig. 6 Correlation between success rate in dual VET and academic education rate 2010-2016, all Swiss cantons. AG Aargau, Al Appenzell Innerrhoden, BL Basel-Landschaft, BS Basel-Stadt, FR Fribourg/Freiburg, GE Genève, GL Glarus, GR Graubünden, JU Jura, LU Luzern, NE Neuchâtel/Neuenburg, NW Nidwalden, OW Obwalden, AR Appenzell Ausserrhoden, BE Bern/Berne, SH Schaffhausen, SO Solothurn, SG St. Gallen, SZ Schwyz, TG Thurgau, TITicino, UR Uri, VD Vaud, VS Valais, ZG Zug, ZH Zürich

Received: 10 May 2020 Accepted: 26 September 2020

Published online: 16 October 2020

\section{References}

Backes-Gellner U, Veen S (2008) The consequences of central examinations on educational quality standards and labour market outcomes. Oxford Rev Educ 34:569-588. https://doi.org/10.1080/03054980701877617 
Backes-Gellner U, Weckmüller H (1998) Ist das Ende der Hauptschule aufzuhalten? Ein informationsökonomischer Beitrag zur Wirkung alternativer Schulregulierungsstrategien auf das Schulnachfrageverhalten. In: von Weizsäcker RK (ed) Deregulierung und Finanzierung des Bildungswesens. Duncker \& Humblot, Berlin, pp 49-77

BFS (2018) Längsschnittanalysen im Bildungsbereich - 90,9\% der jungen Erwachsenen mit einem Abschluss der Sekundarstufe II bis zum 25. Altersjahr. https://www.bfs.admin.ch/bfs/de/home/aktuell/neue-veroeffentlichungen. assetdetail.4282070.html. Accessed 15 Nov 2018

Bolli T (2018) Combining School and Workplace Learning Environments. Presentation (unpublished), Zürich, CEMETS

Bolli T, Egg ME, Rageth L (2017) Meet the need - The role of vocational education and training for the youth labour market. KOF Working Papers No 429 429:. https://doi.org/https://doi.org/10.1088/0264-9381/21/10/010

EDK (2015) Medienmitteilung vom 18.05.2015 - Chancen optimal nutzen: bildungspolitische Ziele für den Bildungsraum Schweiz. https://www.edk.ch/dyn/28578.php. Accessed 15 Nov 2018

Goux D, Gurgand M, Maurin E (2017) Adjusting Your Dreams? High School Plans and Dropout Behaviour. Econ J 127:1025-1046. https://doi.org/10.1111/ecoj.12317

Hampf F, Woessmann L (2017) Vocational vs. general education and employment over the life cycle: New evidence from PIAAC. CESifo Econ Stud 63:255-269. https://doi.org/10.1093/cesifo/ifx012

Hanushek EA, Schwerdt G, Woessmann L, Zhang L (2017) General Education, Vocational Education, and Labor-Market Outcomes over the Lifecycle. J Hum Resour 52:48-87. https://doi.org/10.3368/jhr.52.1.0415-7074R

Hanushek EA, Woessmann L (2011) The economics of international differences in educational achievement. In: Hanushek EA, Machin S, Woessmann L (eds) Handbook of the economics of education. North Holland, Amsterdam, pp 89-200 Konsortium PISA.ch, (2018) PISA 2015. Schülerinnen und Schüler der Schweiz im internationalen Vergleich, Bern and Geneva Luethi S, Wolter SC (2020) Are apprenticeships business cycle proof? Swiss J Econ Stat 156:1-11. https://doi.org/10.1186/ S41937-019-0047-1

Muehlemann S, Pfann G, Pfeifer H, Dietrich H (2018) The Effects of Supply Shocks in the Market for Apprenticeships: Evidence from a German High School Reform. Economics of Education Working Paper Series

Muehlemann S, Wolter SC, Wüest A (2009) Apprenticeship training and the business cycle. Empir Res Voc Educ Train 1:173-186

Mueller B (2016) Four Essays on the Economics of Vocational Education and Training. University of Bern

OECD (2018) More effort needed to improve equity in education. https://www.oecd.org/newsroom/more-effort-neede d-to-improve-equity-in-education.htm. Accessed 15 Nov 2018

Schwerdt G, Woessmann L (2017) The information value of central school exams. Econ Educ Rev 56:65-79. https://doi. org/10.1016/j.econedurev.2016.11.005

SKBF-CSRE (2018) Swiss Education Report 2018. Aarau

SKBF-CSRE (2014) Swiss Education Report 2014. Aarau

Stalder BE (2011) Das intellektuelle Anforderungsniveau beruflicher Grundbildungen in der Schweiz Ratings der Jahre 1999-2005. Institut für Soziologie der Universität Basel/TREE, Basel

VPETA (2002) Federal Act on Vocational and Professional Education and Training

VPETO (2003) Ordinance on Vocational and Professional Education and Training

Wettstein E, Amos J (2010) Schulisch organisierte berufliche Grundbildung (Eine Studie im Auftrag der SBBK). Zurich and Geneva

Woessmann L (2018) Central exit exams improve student outcomes. IZA World of Labor 20:1-10. https://doi. org/10.15185/izawol.419

Wolter SC, Diem A, Messer D (2014) Drop-outs from Swiss Universities: an empirical analysis of data on all students between 1975 and 2008. Eur J Educ 49:471-483. https://doi.org/10.1111/ejed.12096

Wolter SC, Zumbuehl M (2017) The native-migrant gap in the progression into and through upper-secondary education. IZA Discussion Paper No 11217

Zumbuehl M, Wolter SC (2017) Wie weiter nach der obligatorischen Schule? Bildungsentscheidungen und -verläufe der PISA-Kohorte 2012 in der Schweiz. SKBF Staff Paper No 20

\section{Publisher's Note}

Springer Nature remains neutral with regard to jurisdictional claims in published maps and institutional affiliations.

\section{Submit your manuscript to a SpringerOpen ${ }^{\circ}$ journal and benefit from:}

- Convenient online submission

- Rigorous peer review

- Open access: articles freely available online

- High visibility within the field

- Retaining the copyright to your article

Submit your next manuscript at $\boldsymbol{\nabla}$ springeropen.com 